\title{
METHODOLOGICAL ALTERNATIVES IN THE ESTIMATE OF BIOMASS FOR YOUNG INDIVIDUALS OF Bambusa spp.
}

\author{
ALTERNATIVAS METODOLÓGICAS PARA ESTIMATIVA DE BIOMASSA DE \\ INDIVÍDUOS JOVENS DE Bambusa spp.
}

\author{
Lara Clímaco de MELO ${ }^{1}$ Carlos Roberto SANQUETTA²; Ana Paula Dalla CORTE²; \\ Francelo MOGNON ${ }^{1}$ \\ 1. Programa de Pós-Graduação em Engenharia Florestal da Universidade Federal do Paraná, Curitiba, PR, Brasil. \\ laracmelo@gmail.com; 2. Professor (a), Doutor (a) do Departamento de Engenharia Florestal da Universidade Federal do Paraná, \\ Curitiba, PR, Brasil.
}

\begin{abstract}
The objective of this work was to evaluate the distribution of biomass in compartments, as well as to test and select methods to estimate total biomass for species of Bambusa. For the test of the methods were evaluated: method of estimation from allometric models (total and by compartments), application of allometric equation from literature and method that uses the volume, the density and biomass expansion factor (BEF). Were evaluated using the destructive method, 24 bamboos of the species Bambusa oldhamii Munro and Bambusa vulgaris Schrad. ex J. C. Wendl. For the estimation of biomass, were adjusted 5 models for the selection of the best one and the BEF calculated through the values of volume and density. These methodologies were compared among themselves and with the real biomass. The relationship of increased strength of independent variables with dried biomass measured was with dbh. In the adjustment of mathematical models, the best model was the 5 for the total biomass, model 1 for leaf and culm, and the model 3 for the limb. Of the three methodologies for estimating total biomass, the method of Biomass Expansion Factor demonstrated greater accuracy in estimates, being indicated, therefore, the potential use of this methodology.
\end{abstract}

KEYWORDS: Bamboos. Bioenergy. Akaike information criteria. Factor of expansion of biomass. Allometric models.

\section{INTRODUCTION}

The intensification of the natural greenhouse effect as a consequence of increased concentration of greenhouse gases (GHG), particularly $\mathrm{CO}_{2}$, has been implied in global warming, issue discussed by the global scientific community. Researchers have been warning about the limitation of the ecosystems to sustain the anthropic pressure suffered by the environment.

Facing the current scenario in climatic changes, several studies have been contextualizing this theme considering the main activities responsible for the global emissions. The progressive evolution of the global consumption of energy based on in fossil fuels has guided humanity to a polluting and uncertain energy matrix (PROTÁSIO et al., 2013), representative of the highest percentage in GHG emissions, according to IPCC (2007). Thus, through scientific certainty, alternatives that ensure GHG emissions reduction have been increasingly sought.

One of the most efficient and effective alternatives according to specialists is bioenergy, obtained through biomass, a renewable natural resource (Alves, 2011). Among the diversity of biomass sources, the bamboo is considered a useful energy source, considering its chemical composition
(KOBAYASHI et al, 2004) as well as its peculiar growth characteristic and accelerated biomass production, which grants the species a distinctive role, where its usage is described in the global literatures as an excellent exploration strategy, considering its millennial sustainability in multiple uses (MENDOZA et al., 2012; INBAR, 2013).

There are in the world, according to Hidalgo-Lopes (2003), around 1600 bamboo species, distributed in 120 genera, whose geography comprehends tropical, subtropical and temperate regions. Researches like Maoyi (2004) believe there are 22 millions of hectares in the world occupied by bamboos, which would represent a total of $1 \%$ of the planet's forest areas. In addition, Ostapiv e Fagundes (2007) mention a perspective of increase to 2 to $3 \%$ of this total up to the end of the XXI century, considering the diffusion of this culture and the amplification of inventories that allow greater accuracy of the estimates.

The Americas detain 30\% of the total bamboo species, and Brazil is the country holding the greatest diversity, encompassing 34 genera and 232 species (ALMEIDA, 2006), thus reaching, according to Vasconcellos (2006), a bamboo grove area corresponding to 8 millions of hectares. In consideration of this importance, it was sanctioned the law that establishes the National Policy of 
Incentive to Sustainable Management and Bamboo Growth (BRASIL, 2011).

For its natural occurrence in almost every continent, as well as its vast usage possibilities, the increasing predatory exploration of bamboo can be noticed. The different demands should not, however, imply pressure upon theses resources, and for such, it is necessary to ensure sustainability of the exploitation with assessments and studies about ecology and potential, as well as incentives to the production of planted biomass (SCHWARZBACH, 2008; MOREIRA, 2012). A limitation of this development, however, is the lack of seedling suppliers on a commercial scale and in the restrictive scientific information on this grass (ESPELHO, 2007).

The increasing tendency in bamboo exploitation as a renewable resource makes it vital the amplification of markets, where strategic partnerships aiming for the sustainable development of the bamboo's productive chain can enable Brazil to establish an effective economic, social and environmental growth based on this species, taking China as example (OSTAPIV; FAGUNDES, 2007). These considerations support the importance of technical-scientific investigations on the ability of bamboo to provide global environmental services, however, there are still few studies that address this issue (NATH ET al., 2008), especially regarding Brazilian literature (BERALDO; AZZINI, 2004).

The production of bamboo for energetic means will depend on its growth, that among other variables can be determined by the production of biomass (BONILLA, 1991). The estimate of biomass in its turn can be obtained through procedures of low economic cost and reduced environmental impact, making use of models that explain its behavior with adequate precision and accuracy. However, Vasconcellos (2006) complements that are rare the scientific works that quantify the biomass of the several bamboo species in Brazilian territory. For Ostapiv and Fagundes (2007), the reach of beneficent results on the bamboo's productive chain depend on research, innovation and technological diffusion. It is believed, therefore, that constant methodological assessments are vital to contribute to the development of this science.

Considering that, this study aimed to evaluate the distribution of biomass in the compartments, as well testing and selecting methods for the total biomass estimate for the Bambusa genus. For testing the methods were evaluated: method of estimation from allometric models (total and by compartments), application of allometric equation obtained through literature and the method that uses the volume, the density and biomass expansion factor (BEF).

\section{MATERIAL AND METHODS}

\section{Data}

The individuals studied belonged to the experimental plantation of Canguiri farm, belonging to the Federal University of Paraná - UFPR and located in the municipality of Pinhais, metropolitan region of Curitiba, Paraná, Brazil. Utilizing the destructive method, 24 bamboos of the Bambusa oldhamii Munro and Bambusa vulgaris Schrad. ex J. C. Wendl species were analyzed, 12 each, aged between 1 and 3 years old. The data collection of the individuals was carried randomly by selecting representative individuals of the diametric average of the population, as well as free from defects and tortuosity.

In the dendrometric assessment, the dbh $(\mathrm{cm})$, height $(\mathrm{m})$ and stem diameter $(\mathrm{cm})$ values of the individuals were measured. The total volume was obtained through the use of the Smalian equation, and the density determined by dividing the total dry mass according to the volume.

The quantification of the biomass occurred through the felling and weighing of the individuals considering the simple separation method (SANQUETTA et al., 2004), where each individual had their green weight determined by compartment (foliage, branches and stems) on the field through mechanical scaling. Possessing the green biomass data, samples were taken from each compartment, aiming to the drying phase in a greenhouse with an approximate temperature of $70^{\circ} \mathrm{C}$ until reaching constant dry weight to determine the dry biomass. The sum of the biomass of the compartments results in the total aerial biomass.

\section{Biomass Estimates}

To understand the relational force between the variables to be utilized in the study, a correlation matrix was built, using the information form the $\mathrm{dbh}$, height, stem diameter and dry biomass observed through compartments, as well as a graphic assessment of these relations, assisting in the comprehension of these in modeling.

An analysis of the biomass distribution in the different compartments was made, aiming at the knowledge of their allocation. To estimate the biomass, 5 models commonly found in forest literature were adjusted, disposed in Table 1. 
Table 1. Models tested for the biomass estimate of young individuals of the Bambusa genus.

\begin{tabular}{cl}
\hline Number & Models \\
\hline 1 & $\mathrm{dw}=\beta 0+\beta 1\left(\mathrm{dbh}^{2 *} \mathrm{~h}\right)+\mathrm{si}$ \\
2 & $\mathrm{dw}=\beta 0+\beta 1(\mathrm{stemd})+\beta 2 * \mathrm{dbh}^{2}+\beta 3\left(\mathrm{dbh}^{2} \mathrm{~h}\right)+\mathrm{si}$ \\
3 & $\mathrm{dw}=\beta 0+\beta 1(\ln \mathrm{dbh})+s \mathrm{i}$ \\
4 & $\ln \mathrm{dw}=\beta 0+\beta 1(\ln \mathrm{stemd})+\beta 2 *\left(\ln \mathrm{stemd}^{2}\right)+\beta 3\left(\operatorname{lndbh}^{2 *} \mathrm{~h}\right)+s i$ \\
5 & $\mathrm{dw}=\beta 0+\left(\beta 1 \mathrm{dbh}^{0,5}\right) * \ln \mathrm{dbh}+\varepsilon \mathrm{i}$
\end{tabular}

$\mathrm{dw}=\mathrm{dry}$ weight; $\beta \mathrm{n}=$ regression parameters; $\mathrm{Ln}=$ napierian logarithm; stemd=stem diameter; $\mathrm{dbh}=\mathrm{diameter}$ at breast height; $\mathrm{h}=$ total height.

In the models where the dependent variable has been through logarithmic transformation, the Meyer Correction Factor was applied to correct the logarithmic discrepancy. To assess the performance of the adjusted models for the total biomass estimate and by compartments, the following adjustment indicators were analyzed: adjusted coefficient of determination $\left(\mathrm{R}_{\mathrm{aj}}^{2} \mathrm{j}\right)$, the standard error of the estimate $\left(\mathrm{S}_{\mathrm{yx}} \%\right)$, graphic residual analysis, an important indicator of quality and adequate distribution of the adjustment residues, and AIC (Akaike information criterion), which indicate the best covariance structure of the errors.

For the final choice of the best equation, the Weighted Value of Statistical Scores (WV) was utilized, according to the methodology proposed by Thiersch (1997), where weights are assigned to all weighted statistical parameters, considering weight 1 for the most efficient equation, 2 for the second and so on, performing by the end the sum of the score of each isolated model, which will indicate the best model for the total biomass estimate and by compartment. It was adopted as a tiebreaker for the WV the lesser AIC values. The estimates proportioned by the best model constitute one of the tested methodologies to estimate the total biomass.

The calculation of the Biomass Expansion Factor (BEF), obtained through the IPCC-suggested formula (2006), multiplied by the total volume and density data, allowed the estimate of the total biomass for the individuals of the Bambusa genus, being its application the second focus on the generation of estimates.

Where:

$$
\mathrm{BEF}=\frac{\text { Stem Weight }+ \text { Canopy Weight }}{\text { Canopy Weight }}
$$

$\mathrm{BEF}=$ Biomass Expansion Factor;

Stem Weight $=$ Dry weight of the stem $(\mathrm{kg})$;

Canopy Weight $=$ Dry weight of the canopy $(\mathrm{kg})$.

To compose the third scenario of the estimate of biomass, an equation published in the literature for the genus in question was used
(GUOMO et al., 2010). The applied equation is shown below:

$$
\begin{aligned}
& \hat{\mathrm{d}} \mathrm{w}=0.4524 * \mathrm{dbh}^{2.0347} \\
& \text { In which: } \\
& \hat{\mathrm{d}} \mathrm{w}=\text { Dry weight; } \\
& \mathrm{dbh}=\text { Diameter at breast height. }
\end{aligned}
$$

According to Martinelli et al. (1994), the total biomass value can be given through the sum of all its compartments. The sum of branch, stem and leaves biomasses resulted in the total dry biomass, thus constituting the comparative reference for the methodology estimates proposed in this study. Possessing the estimate values through two focuses previously described, efficiency of these methods through descriptive statistics and graphic representation of the observed errors were compared, aiming to understand its behavior and efficacy.

\section{RESULTS AND DISCUSSION}

\section{Allocation of the dry biomass}

The results of average biomass allocation for the Bambusa genus followed the pattern observed in the literature for several species, according to descriptions by Schneider et al. (2004), where the distribution is generally given in the order: wood $>$ branches $>$ bark $>$ leaves. Bringing this reality to the morphology of these species, it was observed that $63 \%$ of the biomass is allocated in the stem compartment, followed by branches and foliage with $22 \%$ and $15 \%$ respectively, disposed in Figure 1 . These results were described by Duking et al. (2011) that report the stem with the largest biomass and carbon stocking.

The allocation of biomass in a study realized with Guadua weber clones, demonstrated that in the aerial parts is where the biggest representative of the total biomass is (60\% to $83 \%$ ), where the biggest values are related to the initial development stages (SILVEIRA, 2001). This observation corroborates with the data found in this data set, considering the 
joviality of the individuals studied and the distribution of obtained biomass.

Total dry biomass

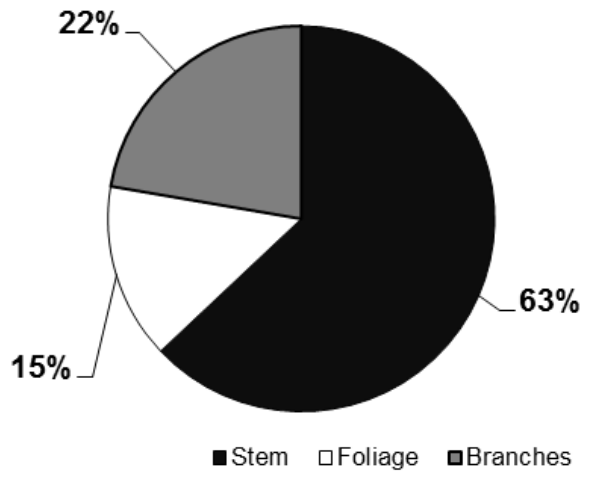

Figure 1. Distribution of the total dry biomass in the compartments of the Bambusa genus.

Miranda et al. (2012) mention that the distribution of biomass follows the morphological and physiological characteristics of the species possibly being affected by soil and climate factors. Therefore, it is important to carried out a careful analysis before applying medium values and allometric equations, aimed at validating them prior to adopting them in studies.

\section{Correlation}

Assessing the relations between the biometric variables utilized in the models through the correlation matrix (Table 2), it was certified that the strongest relation relation with the total dry biomass was through the $\mathrm{dbh}(\mathrm{r}=0,909)$, followed by the stem diameter $(\mathrm{r}=0,826)$ and a little less strong in the total height $(\mathrm{r}=0,736)$.

For the compartment biomasses, it was perceived that the best correlation was through the dbh variable, the stem compartment scoring $r=0,922$, foliage $r=0,828$ and branches $r=0,743$. Even still for the biomass of the compartments the stemd and total height variables presented somewhat inferior correlations related to the $\mathrm{dbh}$.

Table 2. Correlation matrix between the variables utilized in the biomass' estimate of young individuals of the Bambusa genus.

\begin{tabular}{|c|c|c|c|c|c|c|c|}
\hline Variables & stemd $(\mathrm{cm})$ & $\mathrm{dbh}(\mathrm{cm})$ & $\mathrm{h}(\mathrm{m})$ & dw Total & dw Stem & dw Foliage & sw Branches \\
\hline stemd $(\mathrm{cm})$ & 1 & & & & & & \\
\hline $\mathrm{dbh}(\mathrm{cm})$ & 0.943 & 1 & & & & & \\
\hline $\mathrm{h}(\mathrm{m})$ & 0.763 & 0.811 & 1 & & & & \\
\hline dw Total & 0.826 & 0.909 & 0.736 & 1 & & & \\
\hline dw Stem & 0.834 & 0.922 & 0.797 & 0.977 & 1 & & \\
\hline dw Foliage & 0.737 & 0.818 & 0.632 & 0.944 & 0.884 & 1 & \\
\hline dw Branches & 0.692 & 0.743 & 0.494 & 0.877 & 0.772 & 0.828 & 1 \\
\hline
\end{tabular}

$\mathrm{dw}=\mathrm{dry}$ weight, stemd=stem diameter; $\mathrm{dbh}=$ diameter at breast height; $\mathrm{h}=$ height.

The high correlation tendency of the biomass with the dbh variable is observed in several studies with different species, proving its efficiency to explain the biomass' behavior. The authors Silveira (2009), Soares; Oliveira (2002) and Valério et al. (2007), who analyzed the biomass' estimate in Dense Ombrophilous Forest, Eucalyptus population and with the species Hovenia dulcis, respectively, concluded that the presence of this variable is indispensable to the models that objectify the total estimate of biomass and carbon. Corroborating this statement, only this present relation was presented graphically in Figure 2.

The stem and total biomasses showed greater relationship with the dbh variable, when compared to the other compartments, where the dispersions were visually greater. The results have demonstrated the possibility of using allometric models starting from dbh to estimate the biomasses of the studied genus' compartments. 

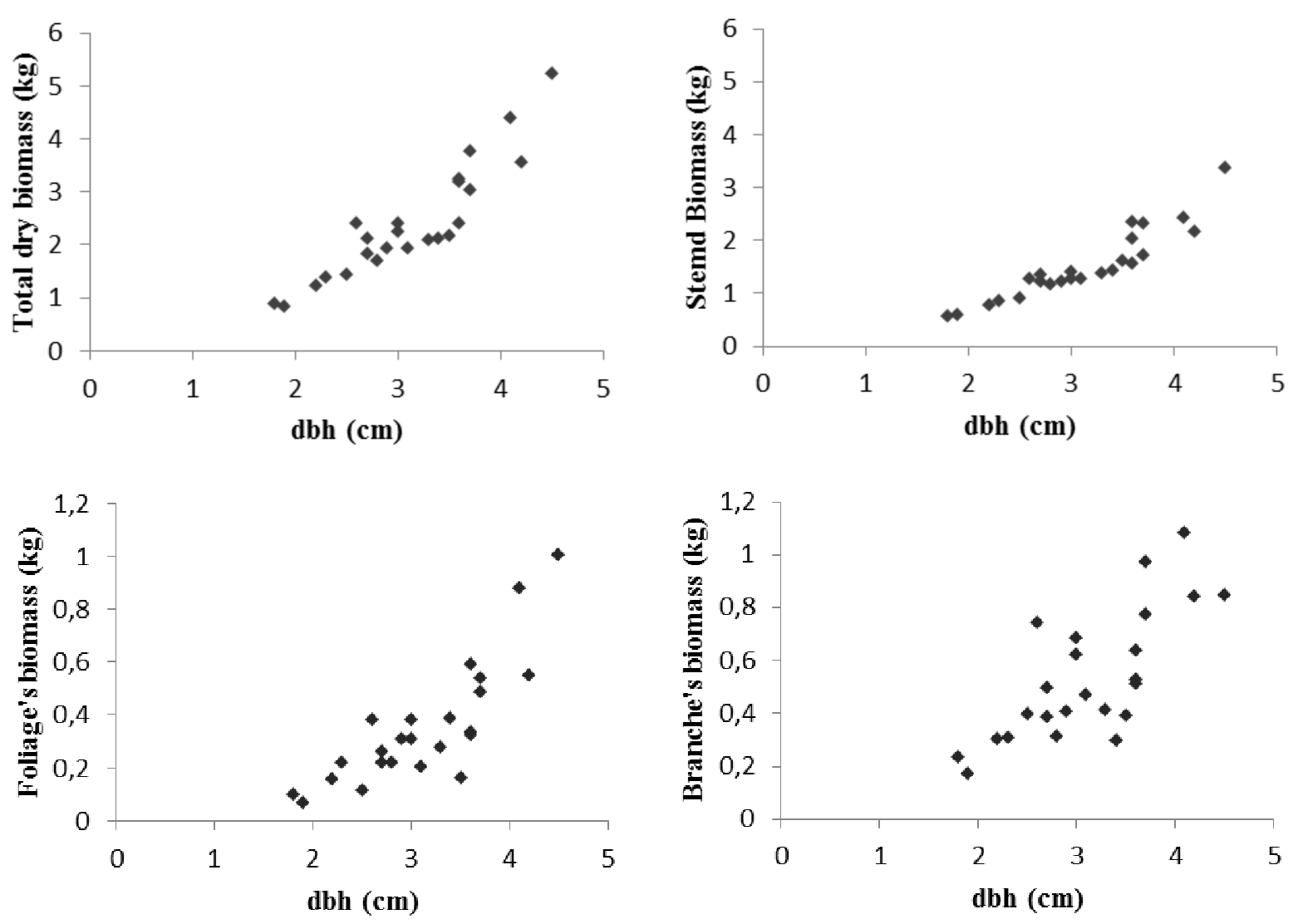

Figure 2. Relation between the dbh variable and the total biomass and by compartment (stem, foliage and branch) of the young individuals of the Bambusa genus.

\section{Methods of the biomass' estimate}

The result obtained in the adjustment of allometric models for the compartments were satisfactory, however, the lower performances were observed for the branches and foliage, represented by the higher Syx (\%), lower $\mathrm{R}_{\text {aj }}^{2}$ and higher AIC coefficients. This premise is coherent with the results demonstrated in the correlation matrix, where these referred compartments obtained lower strength relation with the entry variables of the models. The adjustment statistics are demonstrated in Table 3.

Through the used statistic indicators, model 1 was the one that best estimated the biomass for the stem compartments, followed by model 3 to estimate the branches and model 5 for the total and foliage biomass, considering that these last two express the biomass through the dbh variable, uniquely. Kumaret al. (2005) also found good adjustments for the Bambusa bamboos (L.) Voss through equations that utilized the dbh, with $\mathrm{R}_{\text {aj }}^{2}$ of 0.83 for the total biomass.
It is possible to observe that there is not a greate variance between the statistic indicators obtained in the equations 1 and 3 for the compartments, except for branches, which indicates the possibility of usage of these equations that also presented satisfactory adjustments. The selection proposition should also consider the difficulty level in measuring the variables that are part of the same. It was even observed that the greater AIC values are represented by the equations with greater parameter numbers, considering the weighted behavior of these indicators, that penalize very parametrized models.

The graphic analysis of the residues was carried out for the previously selected equations by the statistical indicators considering the different compartments (models 5, 1, and 3), objectifying verification of the distribution of the selected residues of the selected models, according to Figure 3. 
Table 3. Adjustment statistics of the models to estimate the biomass by compartments of young individuals of the Bambusa genus.

\begin{tabular}{|c|c|c|c|c|c|c|c|c|c|}
\hline \multirow{2}{*}{ Compartment } & \multirow{2}{*}{ Equation } & \multicolumn{4}{|c|}{ Coefficients } & \multicolumn{4}{|c|}{ Adjustment Criteria } \\
\hline & & b0 & b1 & $\mathrm{b} 2$ & b3 & $R^{2} a j$ & Syx $(\%)$ & $\mathrm{AIC}$ & WV \\
\hline \multirow{5}{*}{ Total } & 1 & 0.67545 & 0.02813 & & & 0.85 & 17.56 & 1.28 & 7 \\
\hline & 2 & 0.53765 & -0.0932 & 0.1538 & 0.011085 & 0.85 & 17.46 & 5.49 & 9 \\
\hline & 3 & -1.2013 & 1.78474 & & & 0.84 & 17.67 & 1.26 & 8 \\
\hline & 4 & -1.1139 & -0.0812 & 0.99942 & -0.05381 & 0.83 & 18.47 & 5.27 & 13 \\
\hline & 5 & -0.5699 & 0.67696 & & & 0.98 & 14.45 & 1.54 & 4 \\
\hline \multirow{5}{*}{ Stem } & 1 & 0.41529 & 0.01787 & & & 0.91 & 13.07 & 4.31 & 5 \\
\hline & 2 & 0.34616 & 0.00987 & 0.01515 & 0.015819 & 0.9 & 13.65 & 8.33 & 9 \\
\hline & 3 & -1.6273 & 1.75716 & & & 0.87 & 15.99 & 3.51 & 8 \\
\hline & 4 & -1.191 & -0.2732 & 0.80846 & 0.155437 & 0.86 & 16.2 & 7.64 & 13 \\
\hline & 5 & -1.0061 & 0.66674 & & & 0.79 & 14.88 & 3.79 & 10 \\
\hline \multirow{5}{*}{ Branches } & 1 & 0.2453 & 0.00472 & & & 0.45 & 33.6 & 4.69 & 9 \\
\hline & 2 & 0.11051 & -0.0404 & 0.09488 & -0.00612 & 0.54 & 30.91 & 9.21 & 8 \\
\hline & 3 & -2.4072 & 1.51455 & & & 0.54 & 30.8 & 5.03 & 4 \\
\hline & 4 & -1.6636 & 1.01981 & 1.10498 & -0.65197 & 0.53 & 30.97 & 9.2 & 9 \\
\hline & 5 & -1.8653 & 0.57145 & & & 0.54 & 30.81 & 5.03 & 5 \\
\hline \multirow{5}{*}{ Foliage } & 1 & 0.01487 & 0.00553 & & & 0.7 & 35.6 & 6.11 & 7 \\
\hline & 2 & 0.08098 & -0.0627 & 0.04377 & 0.00139 & 0.7 & 36.01 & 10.26 & 12 \\
\hline & 3 & -3.8062 & 2.31828 & & & 0.72 & 34.84 & 6.2 & 6 \\
\hline & 4 & -3.5088 & -0.0186 & 1.35457 & -0.15649 & 0.7 & 36.06 & 10.25 & 12 \\
\hline & 5 & -2.9908 & 0.8817 & & & 0.76 & 32.09 & 6.53 & 5 \\
\hline
\end{tabular}

$\beta \mathrm{n}=$ regression coefficients.

Total

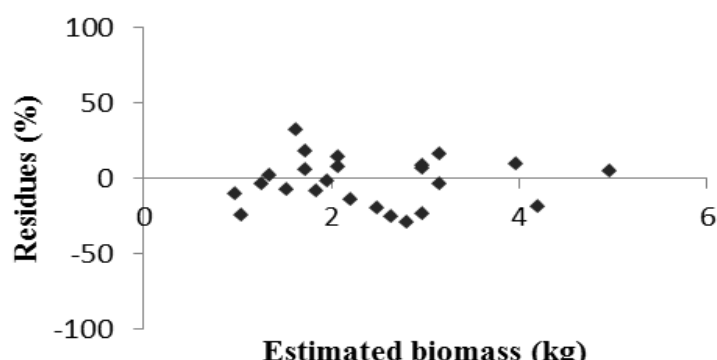

Foliage

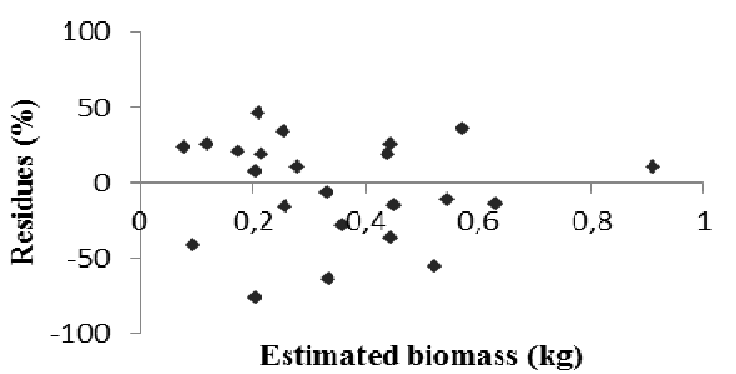

Branches

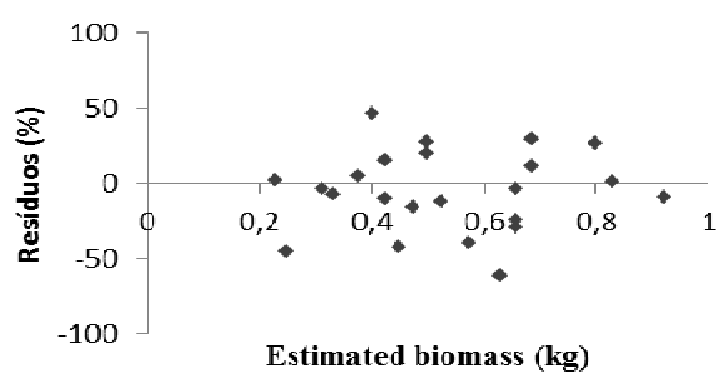

Stem

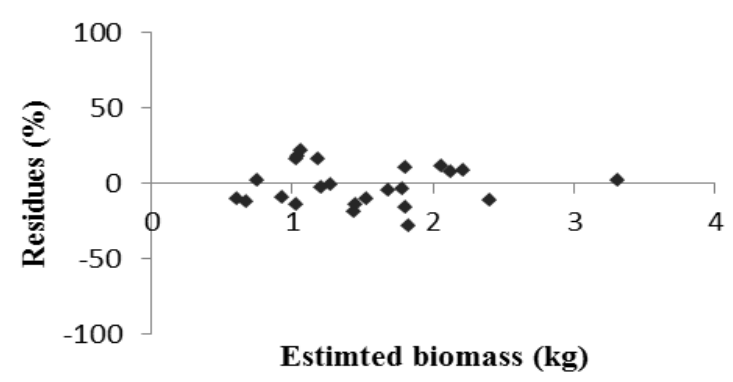

Figure 3. Residual analysis of selected equations for compartments total and foliage (5), stem (1) and branches (3) of young individuals of Bambusa genus. 
As it may be observed, the residues of the selected equation for total biomass were less disperse than foliage and branches compartments, assimilating themselves to the stem compartment residues. Despite being more disperse in branches and foliage, it can be assured that tendencies that could compromise the application of the developed equations didn't occur.

In relation to the $\mathrm{BEF}$, the average value calculated was of 1.58 , the minimum observed value being 1.34 and the maximum 1.885 for the analyzed data set. These values are similar to the ones cited by Tomé (2007), who obtained an average BEF of 1.44 for resinous species in Portugal. Schneider et al. (2005) adopted in their work the approach of volume derivation in biomass and carbon for the species Acacia mearnsii De Wild and came to the conclusion that the estimates were efficient providing low relative error, indicating to be an adequate option for low cost biomass and carbon estimates.

Table 4 presents the comparison of the 4 methodological focuses adopted in this study.

Table 4. Descriptive statistics referring to the biomass estimate methods for young individuals of the Bambusa genus.

\begin{tabular}{lrrrr}
\hline \multirow{2}{*}{ Variables } & \multicolumn{3}{c}{ Methods } \\
\cline { 2 - 5 } & $\mathbf{1}$ & $\mathbf{2}$ & $\mathbf{3}$ & $\mathbf{4}$ \\
\hline Individual Average Total Biomass (kg) & 2.4 & 2.4 & 4.8 & 2.4 \\
Standard Deviation (kg) & 1.02 & 1.07 & 2.13 & 1.1 \\
Variance (kg) & 1.04 & 1.16 & 4.54 & 1.21 \\
Coefficient of Variation (\%) & 42.50 & 44.58 & 44.36 & 45.83 \\
Minimum Total Biomass (kg) & 0.98 & 0.84 & 1.50 & 0.84 \\
Maximum Total Biomass (kg) & 4.97 & 5.23 & 9.65 & 5.23 \\
\hline
\end{tabular}

$1=$ Estimated biomass for the best equation (5); 2 = Estimated biomass for the BEF; 3 = Estimated biomass for Guomo's equation et al. (2012); 4 = Real total biomass.

Descriptive statistics of the estimates of total dry biomass were calculated (method 1,2 and 3 ) and from the observation (method 4). Method 1's values result from the application of the best equation developed for total biomass (model 5), method 2's values come from the adoption of average BEF values calculated based on real available data, applying in the stem values, and method 3's values refer to the application of the equation obtained in the literature for the reality of the Bambusas data.

Taking into consideration the arithmetic average of the individual total biomasses, it is safe to affirm that methods 1 and 2 were precise, once that the methods of the adjusted equation and the BEF reached average estimates of the total biomass equal to the real value. The real standard deviation observed in the estimates also presented similar values, as well as the variation coefficient, demonstrating that this sample set is composed by individuals from different natures in relation to the viable biomass. For method 3, which consists in the application of the literature's equation, there has been an overestimation of the total individual biomass in $100 \%$, also observed in the other descriptive parameters, where the maximum total biomass reached values of 9.65 , almost the double of the observed. This reality demonstrates a low adjustment, indicating a limited application of the referred equation to the data set studied.

The graphic representations of the estimates errors generated by the two best methods, compared to the real total biomass, are shown in Figure 4.

The distribution of the residues of the best adjusted equation (5) observed in Figure 3 is considered satisfactory for the modeling, but it is visible its greatest dispersion in relation to the real values. However, the analysis of the statistics from the BEF method it is more indicated when compared to method 1. For this fact, allied to operational ease, it is recommended the adoption of this approach to estimate the total biomass in this data set.

\section{CONCLUSIONS}

The distribution of biomass in function of its compartments presented as coherent with the described in the literature.

The greater force relation of the independent variables with the dry biomasses measured occurred with the dbh, certifying that the presence of this variable is vital to estimate the biomass of the Bambusa genus

In the adjustment of the mathematical values, the best model was the $5^{\text {th }}$ $\left(\mathrm{ps}=\beta_{0}+\left(\beta_{1} * \mathrm{dbh}^{0,5}\right) * \operatorname{lndbh}\right)$ for the total, branches 
and foliage compartments, and model 1 $\left(\mathrm{ps}=\beta_{0}+\beta_{1} *\left(\mathrm{dbh}{ }^{2 *} \mathrm{~h}\right)\right)$ for the stem compartment.

Of the three methodologies to estimate total biomass, the Biomass Expansion Factor has demonstrated greater accuracy in the estimates, therefore being indicated for the potential use of this methodology.

RESUMO: Esse trabalho tem como objetivo avaliar a distribuição da biomassa nos compartimentos, bem como, testar e selecionar métodos para estimativa de biomassa total para o gênero Bambusa. Para o teste dos métodos foram avaliados: método da estimativa a partir de modelos alométricos, aplicação de equação alométrica obtida por literatura e método que utiliza o volume, a densidade e o fator de expansão da biomassa (FEB). Foram avaliados, utilizando o método destrutivo, 24 bambus das espécies Bambusa oldhamii Munro e Bambusa vulgaris Schrad. ex J. C. Wendl. Para a estimativa de biomassa, foram ajustados 5 modelos para a seleção do melhor e calculado o FEB através dos valores de volume e densidade, metodologias estas comparadas entre si e com a biomassa real. A relação de maior força das variáveis independentes com as biomassas secas mensuradas se deu com o dap. No ajuste dos modelos matemáticos, o melhor modelo foi o 5 para o compartimento total, modelo 1 para folhagem e colmo, e o modelo 3 para os galhos. Das três metodologias de estimativa da biomassa total, o método do Fator de Expansão da Biomassa demonstrou maior acurácia nas estimativas, sendo indicada, portanto, a potencial utilização dessa metodologia.

PALAVRAS-CHAVE: Bambus. Bioenergia. Critério de informação de Akaike. Fator de expansão da biomassa. Modelos alométricos.

\section{REFERENCES}

ALMEIDA, J. G. Proposta para a implantação de uma rede nacional de bambu. In: REDE NACIONAL DE PESQUISA E DESENVOLVIMENTO DO BAMBU, 1. 2006, Brasília. Anais...Brasília: 2006. v. 2, p. 922.

ALVES, I. R. F. S.; SILVA, F. M. S., LINS, M. C. M., SOUZA, N. A. F.; JUCÁ, J. F. T. Avaliação do potencial de geração de biogás do bambu residual proveniente de indústria de papel de celulose. In: II Simpósio Internacional sobre Gerenciamento de Resíduos Agropecuários e Agroindustriais. 2011, Foz do Iguaçu. Anais... Foz do Iguaçu: 2011.

BERALDO, A. L.; AZZINI, A. Bambu características e aplicações. Rio Grande do Sul: Guaíba, Editora Agropecuária Ltda., 2004. 128 p.

BRASIL. Lei $\mathrm{N}^{\circ} 12.484$ de 8 de setembro de 2011- Política Nacionalde Incentivo aoManejo Sustentado e ao Cultivo do Bambu. Diário Oficial República Federativa do Brasil, Brasília, Disponível em: <http://www.planalto.gov.br/ccivil_03/_ato2011-2014/2011/lei/112484.htm>. Acessado em: 20/04/2013.

BONILLA, O. H. Análises quantitativas da produção de Bambusa vulgaris Scharder ex. Wendland no estado da Paraíba. Recife, 1991. 89 f. Dissertação (Mestrado em Biometria) - Universidade Federal Rural do Pernambuco, Recife, 1991.

DUKING, R.; GIELIS, J.; LIESE, W. Carbon flux and carbon stock in a bamboo stand and their relevance for mitigating climate change.The Journal of American Bamboo Society, Encinitas, v. 24, n. 1, p. 1-6.

ESPELHO, J. C. C. Tratamento químico de colmos de bambu pelo método de Boucherie modificado. 2007. 1201 p. Dissertação (Mestrado em Engenharia Agrícola - Área de concentração em Construções Rurais e Ambiência). Universidade Estadual de Campinas, Campinas, 2007.

GUOMO, Z.; YONGJUN, S.; YIPING, L.; JINLIANG, L.; KUEHL, Y.; JIANHUA, C.; GUOQING, M.; YEYUN, H.; XINMIN, W.; TIANFEI, Y. Methodology for Carbon Accounting and Monitoring of Bamboo Afforestation Projects in China. INBAR working Paper, Beijing, n. 73, p. 40, 2012.

HIDALGO LOPEZ, O. Bamboo the gift of the gods. Bogotá, 2003, 553 p. 
INBAR. International network for Bamboo and Rattan. Disponível em: < http://www.inbar.int/publications $>$, acessado em: 06/11/2013.

INTERGOVERNMENTAL PANEL ON CLIMATE CHANGE (IPCC). Guidelines for National Greenhouse Gas Inventories. Em CD ou no site: www.ipcc.ch. Guia de Boas Práticas. 2006.

KOBAYASHI, F.; TAKE, H.; ASADA, C.; NAKAMURA,Y. Methane Production from Steam-Exploded Bamboo. Journal of Bioscience and Bioengineering, Ishikawa, v. 97, n. 6, p. 426-428, 2004.

KUMAR, B. M.; RAJESH, G.; SUDHEESH, K. G. Aboveground biomass production and nutrient uptake of thorny bamboo (Bambusa bambos (L.) Voss) in the homegardens of Thrissur, Kerala. Journal of Tropical Agriculture, Kerala, v. 43, p. 51-56, 2005.

MAOYI, F. Bamboo forestry research. Hangzhou: CBRC - China National Bamboo Research Center, 2004. Hangzhou.

MARTINELLI, L. A.; MOREIRA, M. Z.; BROWN, I. F. Incertezas associadas às estimativas de biomassa em florestas tropicais: o exemplo de uma floresta situada no estado de Rondônia. In: SEMINÁRIO EMISSÃO X SEQÜESTRO DE CO2: uma oportunidade de negócios para o Brasil, 1994, Rio de Janeiro. Anais... Rio de Janeiro: Companhia Vale do Rio Doce, 1994. p. 197-221.

MIRANDA, D. L. C.; SANQUETTA, C. R.; COSTA, L. G. S.; CORTE, A. P. D. Biomassa e Carbono em Euterpe oleracea Mart., na Ilha do Marajó - PA. Floresta e Ambiente, Rio de Janeiro, v. 19, n. 3, p. 336-343, 2012.

MENDOZA, A. C.; HERNÁNDEZ, J. J. V.; GUERRERO, A. G. Componentes de la producción primaria neta aérea en una plantación de Bambusa oldhamii. Agrociencia, Texcoco, v. 46, n. 1, 2012.

MOREIRA, A. C. O. Caracterização de Bambusa vulgaris Schard. ex J.C. Wendl. var. vulgaris, e dos resíduos de caldeira no processo de conversão térmica de energia. 2012. 61 p. Dissertação (Mestrado em Ciências Florestais) - Universidade de Brasília, Brasília, 2012.

NATH, A. J.; DAS, G.; DAS, A. K. Above ground biomass, production and carbon sequestration in farmer managed village bamboo groove in Assam, northeast India. Bamboo Science and Culture, Encinitas, v. 21, n. 1, p. 32-40, 2008.

OSTAPIV, F.; FAGUNDES, E. D. Perspectivas para o desenvolvimento da cultura e da cadeia produtiva do bambu no Paraná, tendo como referência a inovação, a educação tecnológica e o modelo produtivo chinês.

Revista Científica de Educação, Rio de Janeiro, v. 9, n. 9, 2007.

PROTÁSIO, T. P.; BUFALINO, L.; JUNIOR, M. G.; TONOLI, G. H. D.; TRUGILHO, P. F. Técnicas multivariadas aplicas à avaliação de resíduos lignocelulósicos para a produção de bioenergia. Ciência Florestal, Santa Maria, v. 23, n. 4, p. 771-778, 2013.

SANQUETTA, C. R; CORTE, A. P. D.; BALBINOT, R.; ZILLIOTTO, M. A. B. Proposta metodológica para quantificação e monitoramento do carbono estocado em florestas plantadas. In: Carlos Roberto Sanquetta; Marco Aurélio Zilliotto. (Org.). Mercado de carbono: mercado e ciência. Curitiba: Imprensa Universitária UFPR, v. 1, p. 120-150, 2004.

SCHNEIDER, P. R.; FINGER, C. A. G.; HOPPE, J. M.; GIACOMELLI SOBRINHO, V.; SCHNEIDER, P. S. P. Método de derivação do volume em biomassa e carbono: uma aplicação em Platanus x acerifolia (AITON) WILD. SIMPÓSIO LATINO-AMERICANO SOBRE MANEJO FLORESTAL. Santa Maria - RS, 3., Santa Maria. Anais... Santa Maria, UFSM, 2004. 
SCHNEIDER, P. R.; FINGER, C. A. G.; GIACOMELLI SOBRINHO, V.; SCHNEIDER, P. S. P.

Determinação indireta do estoque de biomassa e carbono em povoamentos de acácia-negra (Acacia mearnsii De Wild). Ciência Florestal, Santa Maria, v. 15, n. 4, 2005.

SCHWARZBACH, L. L. C. Bambus e Taquaras: Avaliação e perspectivas de uso sustentável. 2008. 70 p. Dissertação (Mestrado em Ciências) - Departamento de fitotecnia e fitossanitarismo, Setor de Ciências Agrárias, Universidade Federal do Paraná, Curitiba, 2008.

SILVEIRA, M. A floresta aberta com bambu no sudoeste da Amazônia. 2001. 106 p. Tese (Doutorado em Ecologia) - Departamento de Ecologia do Instituto de Ciências Biológicas da Universidade de Brasília, Brasília, 2001.

SILVEIRA, P. Estimativa da biomassa e carbono acima do solo em um fragmento de Floresta Ombrófila Densa utilizando o método da derivação do volume comercial. Floresta, Curitiba, v. 40, n. 4, p. 789-799, 2010.

SOARES, C. P. B.; OLIVEIRA, M. L. R. Equações para estimar a quantidade de carbono na parte aérea de árvores de eucalipto em Viçosa, Minas Gerais. Revista Árvore, Viçosa, v. 26, n. 5, p. 553-539, 2002.

THIERSCH, A. A eficiência das distribuições diamétricas para prognose da produção de Eucalyptus camaldulensis. Lavras, 1997. 155f. Dissertação (Mestrado em Engenharia Florestal) Universidade Federal de Lavras, Lavras, 1997.

VALERIO, A. F.; WATZLAWICK, L. F.; SANTOS, R. T.; SILVESTRE, R.; KOEHLER, H. S.; Ajuste de modelos matemáticos para estimativa de biomassa nos distintos componentes de uva do Japão (Hovenia dulcis Thunb.). Ambiência, Guarapuava, v. 3, n. 3, p. 325-336, 2007.

VASCONCELLOS, R. M. Bambúes en Brasil, una visión histórica y perspectivas futuras. In: SIMPOSIO LATINO AMERICANO DEL BAMBÚ. Guaiaquil, 2006. 